\title{
HUBUNGAN KARAKTERISTIK PASIEN HUMAN IMMUNODEFICIANCY VIRUS (HIV) DENGAN PENGAMBILAN KEPUTUSAN PENGOBATAN DI PUSKESMAS DUPAK
}

\author{
Sindi Paratika ${ }^{1}$, Ernawaty ${ }^{2}$ \\ ${ }^{1,2}$ Departemen Administrasi dan Kebijakan Kesehatan \\ Fakultas Kesehatan Masyarakat Universitas Airlangga ${ }^{1,2}$ \\ Alamat korespondensi: Sindi Paratika \\ Email: sindiparatika@gmail.com
}

\begin{abstract}
Dupak primary health care is one of health care which have complete HIV and Acquired Immuno Deficiency Syndrom (AIDS) prevention program. The number of HIV-AIDS sufferers increasing every year, but the number of new HIV positive cases taking Anti Retroviral Virus(ARV) treatment at Dupak primary health care are low. The purpose of this research was analyzed the HIV treatment decision making process of patients at Dupak primary health care. The method in this research was descriptive quantitive research through questionnaires. Variables of this study are individual characteristics include age, level of education, knowledges, status of severity with decision making process of treatment. The results of this study indicate that most respondents $(50 \%)$ have a high knowledge of HIV treatment. Decision-making process of HIV positive patient treatment have 2 stages that most respondents didn't do. There are stage of the information search (75\%) and stage of alternative evaluation (56.25\%). The conclusion of this research are most respondents didn't do information searching and alternative evaluation in decision making process at Dupak primary health care. According suggested from this study are to improve HIV related socialization programs through promotional activities and discussions related to HIV treatment services to improve knowledge and activeness of seeking information through print and electronic media.
\end{abstract}

Keywords: decision-making process, HIV positive patients, knowledge, primary health care, severity level

\begin{abstract}
ABSTRAK
Puskesmas Dupak adalah salah satu puskesmas yang memiliki program penanggulangan HIV dan AIDS secara lengkap. Jumlah penderita HIV-AIDS mengalami peningkatan setiap tahunnya, namun jumlah kasus baru HIV positif yang melakukan pengobatan ARV di Puskesmas Dupak tergolong rendah. Penelitian ini digunakan untuk menganalisis proses pengambilan keputusan pasien untuk melakukan pengobatan HIV di Puskesmas Dupak. Penelitian ini adalah penelitian kuantitatif deskriptif melalui hasil kuesioner. Variabel penelitian ini adalah hubungan karakteristik individu yang meliputi umur, tingkat pendidikan, pengetahuan, status keparahan dengan proses pengambilan keputusan pengobatan. Hasil penelitian ini menunjukkan bahwa sebagian besar responden memiliki pengetahuan pengobatan HIV yang tinggi sebesar 50\%. Proses pengambilan keputusan pengobatan terdapat 2 tahap yang sebagian besar tidak dilakukan oleh responden yaitu pada tahap information search sebesar $75 \%$ dan tahap evaluation alternative sebesar 56,25\%. Kesimpulan dari penelitian ini adalah sebagian besar responden tidak melakukan tahap information search dan evaluation alternative pada proses pengambilan keputusan pengobatan di Puskesmas Dupak. Saran dari penelitian ini adalah meningkatkan program sosialisasi terkait HIV melalui kegiatan promosi dan diskusi terkait pelayanan pengobatan HIV untuk meningkatkan pengetahuan dan keaktifan mencari informasi melalui media cetak maupun media elektronik.
\end{abstract}

Kata kunci : proses pengambilan keputusan, pasien HIV positif, pengetahuan, puskesmas, status keparahan

\section{PENDAHULUAN}

Indonesia memiliki komitmen untuk mengendalikan epidemi kasus HIV yang cenderung selalu meningkat setiap tahunnya, sehingga Indonesia mencantumkan target sebesar kurang dari $0,50 \%$ terhadap pengendalian HIV pada tahun 2019 melalui pembangunan Rencana Pembangunan Jangka Menengah Nasional (RPJMN). Virus HIV menyerang bagian sistem kekebalan tubuh terutama sel CD4 
yang membantu sistem kekebalan tubuh manusia (Ardhiyanti, 2015).

HIV pertama kali ditemukan pada tahun 1987 sampai dengan bulan September tahun 2016, jumlah kasus HIV dan AIDS tersebar di 407 dari 507 kabupaten/kota di seluruh Provinsi di Indonesia. Jumlah kasus HIV yang telah dilaporkan pada tahun 2014 yaitu sebanyak 32.711 kasus HIV, pada tahun 2015 yaitu sebanyak 30.935 kasus HIV dan pada tahun 2016 dilaporkan sebanyak 27.963 kasus HIV. Jumlah infeksi HIV pada tahun 2016 pada bulan Juli hingga September yaitu sebanyak 10.116 kasus infeksi HIV, sedangkan jumlah AIDS dilaporkan sebanyak 412 kasus AIDS (Kemenkes RI Ditjen PP dan PL Tahun 2016).

Statistika kasus HIV dan AIDS di Indonesia tertinggi berada di Provinsi DKI Jakarta yaitu sebanyak 43.738 kasus, sedangkan Propinsi Jawa Timur berada di posisi tertinggi kedua kasus HIV yaitu sebanyak 28.979 kasus HIV. Jumlah AIDS di Indonesia tertinggi berada di Provinsi Jawa Timur yaitu sebanyak 16.432 kasus, sedangkan Provinsi dengan jumlah AIDS tertinggi kedua adalah Provinsi Papua yaitu sebanyak 13.335 kasus AIDS (Kemenkes RI Ditjen PP dan PL Tahun 2016). Menurut data Dinas Kesehatan Kota Surabaya pada tahun 2013-2016, jumlah temuan kasus baru HIV dan AIDS mengalami peningkatan sebanyak $24,0 \%$ pada tahun 2014 kemudian mengalami penurunan sebanyak $0,21 \%$ pada tahun 2015 dan pada tahun 2016 mengalami penurunan sebanyak $1,07 \%$.

Perkembangan kasus HIV dan AIDS hingga saat ini masih menjadi tantangan besar untuk daerah-daerah yang sedang berkembang (Inggit, 2017). Penanganan HIV dan AIDS diperlukan perhatian yang serius dari berbagai pihak, hal ini dikarenakan penyakit HIV dan AIDS menurunkan daya tahan tubuh sehingga dapat menyebabkan kualitas hidup dan produktifitas bangsa juga mengalami penurunan (Elly, 2009).
Menurut Permenkes Nomor 75 tahun 2014, Puskesmas adalah unit pelaksana teknis daerah (UPTD) Dinas Kesehatan kabupaten/kota dan merupakan pelaksana tingkat pertama pembangunan kesehatan di Indonesia. Puskesmas diharapkan memberikan layanan dukungan, perawatan, dan pengobatan HIV secara mandiri sesuai dengan standard layanan di fasilitas tingkat pertama (Sugiana, 2015).

Puskesmas Dupak merupakan salah satu puskesmas yang dinyatakan sebagai puskesmas rujukan dan menjadi satelit ARV di Kota Surabaya. Puskesmas Dupak juga memiliki penanggulangan HIV dan AIDS secara lengkap yang melaksanakan Layanan Kesehatan Berkesinambungan (LKB). Pelaksanaan layanan baik melalui dukungan, perawatan dan pengobatan sudah dilaksanakan oleh Puskesmas Dupak sebagai upaya untuk mengendalikan penyakit menular di wilayah kerjanya, namun jumlah temuan kasus baru HIV di Puskesmas Dupak tergolong tinggi setiap tahunnya.

Jumah kasus baru HIV positif di Puskesmas Dupak masih tinggi setiap tahunnya. Tahun 2015, jumlah kasus baru HIV positif di Puskesmas Dupak sebesar 22 orang yang berasal dari poli umum dan 4 orang berasal dari poli Kesehatan Ibu dan Anak (KIA). Tahun 2016, jumlah kasus baru HIV positif di Puskesmas Dupak sebesar 20 orang yang berasal dari poli umum dan 2 orang berasal dari poli KIA. Menurut manajer kasus yang menangani kasus HIV dan AIDS di Puskesmas Dupak, pasien yang dinyatakan sebagai HIV positif yang berasal dari poli KIA langsung dirujuk ke Rumah Sakit dr. Soetomo, sehingga pengobatan HIV yang dilaksanakan di Puskesmas Dupak berasal dari pasien yang melakukan Provider Initiated Testing and Counselling (PITC) di poli umum dan poli TB.

Penemuan pengobatan HIV dengan menggunakan terapi ARV adalah suatu perkembangan perawatan kepada Orang dengan HIV AIDS (ODHA) (Adhithyan, 
2016). Menurut laporan HIV dan AIDS P2P Kemenkes RI tahun 2016, menunjukkan bahwa jumlah ODHA yang telah mendapatkan pengobatan ARV hingga bulan September tahun 2016 sebanyak 73.037 orang. Kelangsungan pengobatan HIV dan AIDS di Puskesmas Dupak pada tahun 2014 ditemukan kasus baru sebanyak 10 kasus yang kemudian pasien memutuskan untuk berobat di Puskesmas Dupak sebanyak 9 orang, berobat pada fasilitas kesehatan lainnya sebanyak 1 orang. Tahun 2015 sebanyak 22 kasus yang kemudian pasien memutuskan untuk berobat di Puskesmas Dupak sebanyak 1 orang, data pasien meninggal sebanyak 2 orang. Sebanyak 19 pasien HIV positif lainnya memutuskan untuk melakukan pengobatan di fasilitas layanan kesehatan lainnya yang melayani pengobatan HIV atau pelayanan kesehatan layanan rujukan ARV.

Laporan tahun 2017 dari Puskesmas Dupak menyebutkan, bila jumlah kasus baru HIV positif pada tahun 2016 sebanyak 20 kasus. Pasien yang melakukan pengobatan HIV di Puskesmas Dupak sebanyak 2 orang, pasien meninggal sebanyak 2 orang, sedangkan pasien kasus baru HIV positif yang melakukan pengobatan di fasilitas kesehatan lainnya sebanyak 16 orang. Jumlah ditemukan pasien kasus baru HIV positif yang melakukan pemeriksaan tes HIV awal di Puskesmas Dupak mencapai angka yang tinggi setiap tahunnya. Jumlah pasien kasus baru HIV positif yang melakukan pengobatan HIV di Puskesmas Dupak tergolong pada angka rendah yaitu sebanyak 2 orang atau $10 \%$ dari jumlah pasien kasus baru HIV positif di Puskesmas Dupak pada tahun 2016.

Rendahnya penggunaan fasilitas layanan kesehatan dipengaruhi oleh beberapa faktor yaitu faktor dari penyedia layanan dan faktor masyarakat. Faktor yang berasal dari penyedia layanan meliputi fasilitas yang disediakan oleh pelayanan kesehatan, jarak, dan biaya untuk memperoleh pelayanan kesehatan.
Faktor yang berasal dari masyarakat meliputi tingkat pendidikan dan status sosial ekonomi masyarakat (Swasta, 2005). Kualitas pelayanan puskesmas, citra layanan kesehatan di puskesmas, dan citra tenaga kesehatan dapat mempengaruhi pengambilan keputusan untuk menggunakan layanan kesehatan (Arwyn, 2017).

Berdasarkan latar belakang, terdapat berbagai faktor yang dapat mempengarui pengambilan keputusan pada pasien HIV positif dalam penggunaan layanan kesehatan untuk pengobatan dan penanganan penyakit HIV dan AIDS, sehingga peneliti tertarik untuk meneliti hubungan antara faktor individi pasien HIV positif untuk melakukan pengambilan keputusan pengobatan di Puskesmas Dupak Kota Surabaya. Penelitian ini bertujuan untuk mengetahui hubungan antara faktor karakteristik individu yang meliputi umur, tingkat pendidikan, pengetahuan dan status keparahan dengan proses pengambilan keputusan pengobatan pasien HIV positif di Puskesmas Dupak Kota Surabaya (Notoatmojo, 2003).

\section{METODE PENELITIAN}

Penelitian ini merupakan penelitian kuantitatif deskriptif melalui hasil kuesioner dengan menggunakan rancang bangun cross-sectional. Populasi dalam penelitian ini adalah seluruh pasien yang telah dinyatakan sebagai pasien HIV positif dan melakukan pengobatan di Puskesmas Dupak dengan karakteristik yang ditentukan melalui kriteria inklusi. Kriteria inklusi pada penelitian ini yaitu responden telah dinyatakan menjadi pasien kasus baru HIV positif di Puskesmas Dupak Surabaya, pasien HIV positif yang melakukan pengobatan di Puskesmas Dupak, pasien HIV positif yang datang saat acara sosialisasi pada tanggal 14 Agustus 2017, serta bersedia menjadi responden.

Responden dalam penelitian ini sebanyak 16 pasien HIV positif yang 
melakukan pengobatan di Puskesmas Dupak. Penelitian ini dilakukan di Puskesmas Dupak yang berlokasi di Jl. Dupak Bangunrejo Gg. Poliklinik No. 6 Kecamatan Krembangan Kota Surabaya. Variabel independen dalam penelitian ini adalah faktor karakteristik pasien HIV positif yang meliputi umur, tingkat pendidikan, pengetahuan, serta status keparahan pasien HIV positif yang melakukan pengobatan di Puskesmas Dupak. Variabel dependen pada penelitian ini adalah proses pengambilan keputusan pengobatan di Puskesmas Dupak.

Penelitian ini menggunakan teori pengambilan keputusan menurut Solomon, Gary, Soren, Margaret, dan Hogg dalam buku "Consumer Behaviour Third Edition" pada tahun 2006. Berdasarkan teori Solomon et al (2006), terdapat 5 tahap pengambilan keputusan yaitu tahap problem recognition, information search, evaluation of alternative, purchase, dan outcome. Data yang telah diperoleh kemudian dianalisis dengan menggunakan teknik analisis deskriptif berupa distribusi frekuensi dan tabulasi silang (crosstabulation). Penelitian ini telah mendapatkan keterangan lolos uji etik yang berasal dari Komisi Etik Penelitian Kesehatan Fakultas Kesehatan Masyarakat No. 434-KEPK.

\section{HASIL}

\section{Karakteristik Pasien HIV Positif yang Melakukan Pengobatan di Puskesmas Dupak}

Karakteristik responden pada penelitian ini meliputi umur, tingkat pendidikan, pengetahuan, dan status keparahan pasien HIV positif yang berobat di Puskesmas Dupak. Umur adalah jumlah tahun hidup pasien HIV positif mulai dari lahir hingga saat dilakukan pengisian lembar kuesioner di Puskesmas Dupak. Pengelompokkan umur pasien HIV positif pada penelitian ini dikelompokkan berdasarkan rentang umur menurut Departemen Kesehatan tahun 2009 yaitu balita (0-5 tahun), anak-anak (5-11 tahun), remaja (12-25 tahun), dewasa (26-45 tahun), lansia (46-65 tahun), dan manula (lebih dari 65 tahun).

Tingkat pendidikan pasien HIV positif pada penelitian ini dilihat berdasarkan jenjang pendidikan formal yang ditempuh oleh responden yang meliputi tidak sekolah, Sekolah Dasar (SD), Sekolah Menengah Pertama (SMP), Sekolah Menengah Atas (SMA), dan Perguruan Tinggi. Pengetahuan pasien HIV positif yang melakukan pengobatan dalam penelitian ini dikelompokkan menjadi 3 kategori yaitu pengetahuan tinggi, sedang dan rendah. Status keparahan pasien HIV positif pada penelitian ini ditinjau dari tingkat stadium pasien HIV positif saat melakukan pengobatan di Puskesmas Dupak Kota Surabaya yaitu stadium I, stadium II, stadium III, dan Stadium IV.

Berdasarkan Tabel 6, menunjukkan bahwa rentang umur responden yang melakukan pengobatan di Puskesmas Dupak pada kelompok remaja, dewasa, hingga lansia. Rentang kelompok umur pasien HIV positif yang menjadi responden dalam penelitian ini adalah 23-55 tahun. Sebagian besar kelompok umur responden yang melakukan pengobatan di Puskesmas Dupak dengan memiliki persentase tertinggi adalah pada rentang usia dewasa yaitu sebesar $75,0 \%$. Tingkat pendidikan responden diukur sesuai dengan jenjang pendidikan formal yang telah ditempuh oleh pasien HIV positif di Puskesmas Dupak. Berdasarkan Tabel 6, menunjukkan bahwa tingkat pendidikan formal yang telah ditempuh responden mayoritas tamatan SMA dengan persentase sebesar $43,75 \%$, sedangkan responden yang menempuh pendidikan formal tamatan SMP sebesar 25,0\% dan tamatan SD sebesar $31,25 \%$.

Tingkat pengetahuan responden menunjukkan bahwa sebagian besar dalam kategori tinggi dengan peresentase tertinggi yaitu sebesar 50,0\%. Pengetahuan responden termasuk dalam kategori tinggi 
karena telah mengetahui terkait dengan arti pengobatan HIV, fungsi pengobatan HIV, manfaat pengobatan HIV, efek samping tidak menyelesaikan pengobatan HIV, efek samping mengkonsumsi obat HIV, serta konsekuensi mengkonsumsi pengobatan HIV yang dikonsumsi seumur hidup.

Tabel 1. Data Distribusi Karakteristik Responden yang Melakukan Pengobatan di Puskesmas Dupak Tahun 2017

\begin{tabular}{|c|c|c|}
\hline $\begin{array}{c}\text { Karakteristik } \\
\text { Individu }\end{array}$ & $\begin{array}{c}\text { Jumlah } \\
\text { (n) }\end{array}$ & $\begin{array}{c}\text { Persentase } \\
(\%)\end{array}$ \\
\hline \multicolumn{3}{|l|}{ Umur (Tahun) } \\
\hline Remaja (12-25) & 1 & 6,25 \\
\hline Dewasa (26-45) & 12 & 75,00 \\
\hline Lansia (46-55) & 3 & 18,75 \\
\hline Total & 16 & 100,00 \\
\hline \multicolumn{3}{|l|}{ Pendidikan } \\
\hline SD & 5 & 31,25 \\
\hline SMP & 4 & 25,00 \\
\hline SMA & 7 & 43,75 \\
\hline Total & 16 & 100,00 \\
\hline \multicolumn{3}{|l|}{ Pengetahuan } \\
\hline Tinggi & 8 & 50,00 \\
\hline Sedang & 4 & 25,00 \\
\hline Rendah & 4 & 25,00 \\
\hline Total & 16 & 100,00 \\
\hline \multicolumn{3}{|l|}{ Status Keparahan } \\
\hline Stadium I & 1 & 6,25 \\
\hline Stadium II & 4 & 25,00 \\
\hline Stadium III & 7 & 43,75 \\
\hline Stadium IV & 4 & 25,00 \\
\hline Total & 16 & 100,00 \\
\hline
\end{tabular}

Status keparahan dilihat dari tingkat stadium pasien HIV positif yang melakukan pengobatan di Puskesmas Dupak. Tingkat stadium pada penyakit HIV meliputi Stadium I, Stadium II, Stadium III, dan Stadium IV. Status keparahan pasien HIV yang melakukan pengobatan di Puskesmas Dupak sebagian besar dalam kondisi tingkat keparahan pada stadium III yaitu sebesar $43,75 \%$.

\section{Pengambilan Keputusan Pengobatan Pasien HIV Positif}

Keputusan adalah hasil dari sebuah proses yang dipengaruhi oleh beberapa faktor termasuk pengetahuan dan lingkungan, sehingga pengambilan keputusan merupakan sebuah proses pemikiran dan pertimbangan yang dilakukan secara mendalam dan sistemik dengan langkah-langkah yang berurutan. Menurut Marquis dan Husto (2010), pengambilan keputusan merupakan proses atau upaya untuk memutuskan serangkaian tindakan, sehingga keputusan sering dianggap sinonim denga manajemen. George R Terry dalam Gita Farelya (2015) menyatakan bahwa pengambilan keputusan merupakan sebuah pemilihan yang didasari dengan kriteria tertentu pada dua atau lebih alternative, terdapat 5 hal pokok dalam pengambilan keputusan yaitu intuisi berdasarkan perasaan, pengalaman, fakta, wewenang, dan rasional. Menurut Solomon et al (2006), terdapat 5 tahap dalam melakukan pengambilan keputusan yaitu problem recognition, information search, evaluation of alternative, purchase, dan ourcome.

Berdasarkan Tabel 2, menunjukkan bahwa alasan responden melakukan pengobatan yaitu berasal dari keinginan diri sendiri memiliki prsentase tertinggi yaitu sebesar $68,75 \%$. Identifikasi tahap information search dilihat dari keaktifan responden mencari informasi pelayanan pengobatan HIV baik di Puskesmas maupun fasilitas kesehatan lainnya. Berdasarkan Tabel 2 menunjukkan bahwa sebagian besar responden tidak aktif melakukan pencarian informasi terkait pelayanan pengobatan di Puskesmas Dupak maupun fasilitas kesehatan lainnya sebesar $56,25 \%$.

Identifikasi pada tahap evaluation of alternative dalam penelitian ini dilihat dari keaktifan responden melakukan perbandingan pelayanan pengobatan di 
Puskesmas Dupak maupun di fasilitas kesehatan lainnya. Berdasarkan Tabel 2 menunjukkan bahwa sebagian besar dari jumlah total responden sebanyak $62,50 \%$ pasien HIV positif tidak melakukan perbandingan dan penilaian terhadap tempat pelayanan pengobatan HIV di Puskesmas Dupak.

Tabel 2. Distribusi Tahap Pengambilan Keputusan Pengobatan di Puskesmas Dupak Tahun 2017

\begin{tabular}{lrr}
\hline $\begin{array}{c}\text { Tahapan } \\
\text { Pengambilan } \\
\text { Keputusan }\end{array}$ & $\begin{array}{c}\text { Jumlah } \\
(\mathbf{n})\end{array}$ & \multicolumn{1}{c}{$\begin{array}{c}\text { Persentase } \\
(\boldsymbol{\%})\end{array}$} \\
\hline $\begin{array}{l}\text { Problem Recognition } \\
\text { Keingian sendiri }\end{array}$ & 11 & 68,75 \\
Dorongan & 5 & 31,25 \\
Total & 16 & 100,00 \\
& & \\
Information Search & & \\
Aktif & 7 & 43,75 \\
Tidak Aktif & 9 & 56,25 \\
Total & 16 & 100,00 \\
& & \\
Evaluation of Alternatif & & \\
Aktif & 6 & 37,50 \\
Tidak Aktif & 10 & 62,50 \\
Total & 16 & 100,00 \\
& & \\
Purchase & & \\
Diri Sendiri & 12 & 75,00 \\
Dorongan orang & 4 & 25,00 \\
lain & & \\
Total & 16 & 100,00 \\
\hline
\end{tabular}

Identifikasi pada tahap purchase adalah dilihat dari subjek yang mempengaruhi responden untuk melakukan pengobatan di Puskesmas Dupak. Tabel 2 menunjukkan bahwa keputusan pembelian pengobatan pasien HIV positif di Puskesmas Dupak sebagian besar berasal dari dorongan terhadap keinginan atau kebutuhan yang berasal dari diri sendiri memiliki persentase tertinggi yaitu sebesar $75,0 \%$.

\section{Hubungan Karakteristik Individu dengan Tahap Problem Recognition di Puskesmas Dupak}

Problem recognition adalah proses yang terjadi saat seseorang melihat perbedaan yang signifikan antara keadaan saat ini dan keadaan yang diinginkan atau yang dibutuhkan (Solomon et al, 2006). Keinginan dan kebutuhan dipengaruhi oleh faktor internal dan eksternal yang menjadi dorongan bagi seseorang untuk mendapatkan kepuasan terhadap keinginan dan kebutuhan pada diri seseorang (Trihono, 2005).

Faktor internal dan eksternal yang dapat mempengaruhi proses seseorang melakukan pengambilan keputusan adalah faktor pribadi, faktor psikologis, faktor budaya, maupun faktor social (Schiffman dan Kanuk, 2007). Faktor pribadi meliputi usia, pekerjaan, kepribadian, dan gaya hidup. Faktor psikologis mliputi motivasi, persepsi, pembelajaran, memori, dan kepercayaan. Faktor budaya meliputi budaya, sub budaya, dan kelas sosial. Faktor sosial meliputi keluarga, peran, dan status (Notoatmojo, 2003).

Berdasarkan Tabel 3, menunjukkan bahwa semakin tua umur pasien maka pengenalan kebutuhan untuk melakukan pengobatan HIV di Puskesmas Dupak yang berasal dari keinginan diri pasien cenderung semakin tinggi. Tabel 3 menunjukkan bahwa semakin rendah tingkat pendidikan pasien maka pengenalan kebutuhan pengobatan HIV di Puskesmas Dupak yang berasal dari keinginan diri sendiri cenderung semakin tinggi. Berdasarkan pengetahuan responden, sebagian besar alasan responden yang melakukan pengobatan di Puskesmas Dupak yang berasal dari keinginan didominasi oleh responden yang cenderung memiliki tingkat pengetahuan yang tinggi. Tabel 3 menunjukkan bahwa mayoritas responden melakukan pengobatan HIV di Puskesmas Dupak yang berasal dari keinginan pasien sendiri didominasi oleh stadium I dan stadium IV. 
Tabel 3. Hubungan Karakteristik Individu dengan Tahap Problem Recognition Pengobatan HIV di Puskesmas Dupak

\begin{tabular}{|c|c|c|c|c|c|}
\hline \multirow{2}{*}{$\begin{array}{l}\text { Karak- } \\
\text { teristik }\end{array}$} & \multicolumn{3}{|c|}{ Problem Recognition } & \multicolumn{2}{|c|}{ Total } \\
\hline & $\%$ & $\mathbf{n}$ & $\%$ & $\mathbf{n}$ & $\%$ \\
\hline
\end{tabular}

\begin{tabular}{lrrrrrr}
\hline Umur & & & & & & \\
Remaja & 0 & 0,0 & 1 & 100,0 & 1 & 100,0 \\
Dewasa & 8 & 66,7 & 4 & 33,3 & 12 & 100,0 \\
Lansia & 3 & 100,0 & 0 & 0,0 & 3 & 100,0
\end{tabular}

Tingkat Pendidikan

$\begin{array}{lllllll}\text { SD } & 4 & 80,0 & 1 & 20,0 & 5 & 100,0 \\ \text { SMP } & 2 & 50,0 & 2 & 50,0 & 4 & 100,0 \\ \text { SMA } & 5 & 71,4 & 2 & 28,6 & 7 & 100,0\end{array}$

Pengetahuan

$\begin{array}{lrrrrrr}\text { Tinggi } & 5 & 62,5 & 3 & 37,5 & 8 & 100,0 \\ \text { Sedang } & 2 & 50,0 & 2 & 50,0 & 4 & 100,0 \\ \text { Rendah } & 4 & 100,0 & 0 & 0,0 & 4 & 100,0\end{array}$

Status Keparahan

$\begin{array}{lllllll}\text { Stad. I } & 1 & 100,0 & 0 & 0,0 & 1 & 100,0\end{array}$

$\begin{array}{lllllll}\text { Stad. II } & 1 & 25,0 & 3 & 75,0 & 4 & 100,0\end{array}$

$\begin{array}{lllllll}\text { Stad. } & 5 & 71,4 & 2 & 28,6 & 7 & 100,0\end{array}$

III

$\begin{array}{lllllll}\text { Stad. } \quad & 4 & 100,0 & 0 & 0,0 & 4 & 100,0\end{array}$

IV

Keterangan: Stad. $=$ Stadium

\section{Hubungan Karakteristik Individu dengan Tahap Information Search di Puskesmas Dupak}

Information search adalah proses seseorang mengamati lingkungan untuk mendapatkan suatu informasi sesuai dengan kebutuhan untuk membuat sebuah keputusan (Solomon et al, 2006). Berdasarkan Tabel 4 menunjukkan bahwa semakin tua umur responden, maka pencarian informasi terkait pelayanan pengobatan cenderung semakin menurun. Karakteristik pada tingkat pendidikan responden menunjukkan bahwa semakin rendah pendidikan pasien yang melakukan pengobatan HIV di Puskesmas Dupak, maka semakin tidak aktif responden melakukan pencarian informasi terkait pelayanan pengobatan di Puskesmas Dupak.

Tabel 4. Hubungan Karakteristik Individu dengan Tahap Information Search Pengobatan HIV di Puskesmas Dupak

\begin{tabular}{lrrrrrr}
\hline Karak- & \multicolumn{9}{c}{ Information Search } \\
teristik & Aktif & \multicolumn{2}{c}{$\begin{array}{c}\text { Tidak } \\
\text { Aktif }\end{array}$} & Total \\
& n & $\%$ & n & $\%$ & n & $\%$ \\
\hline Umur & & & & & & \\
Remaja & 1 & 100,0 & 0 & 0,0 & 1 & 100,0 \\
Dewasa & 3 & 25,0 & 9 & 75,0 & 12 & 100,0 \\
Lansia & 0 & 0,0 & 3 & 100,0 & 3 & 100,0
\end{tabular}

Tingkat Pendidikan

$\begin{array}{lrrrrrr}\text { SD } & 0 & 0,0 & 5 & 100,0 & 5 & 100,0 \\ \text { SMP } & 2 & 50,0 & 2 & 50,0 & 4 & 100,0 \\ \text { SMA } & 2 & 28,6 & 5 & 71,4 & 7 & 100,0\end{array}$

Pengetahuan

$\begin{array}{lllllll}\text { Tinggi } & 3 & 37,5 & 5 & 62,5 & 8 & 100,0 \\ \text { Sedang } & 1 & 25,0 & 3 & 75,0 & 4 & 100,0 \\ \text { Rendah } & 0 & 0,0 & 4 & 100,0 & 4 & 100,0 \\ & & & & & & 100,0\end{array}$

Status Keparahan

$\begin{array}{lllllll}\text { Stad. I } & 0 & 0,0 & 1 & 100,0 & 1 & 100,0\end{array}$

$\begin{array}{lllllll}\text { Stad. II } & 1 & 25,0 & 3 & 75,0 & 4 & 100,0\end{array}$

$\begin{array}{lllllll}\text { Stad. III } & 1 & 14,3 & 6 & 85,7 & 7 & 100,0\end{array}$

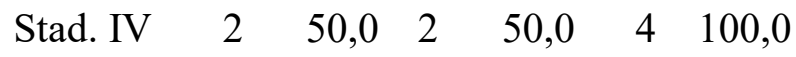

Keterangan: Stad. $=$ Stadium

Berdasarkan Tabel 4, hubungan antara pengetahuan dengan tahap information search di Puskesmas Dupak yaitu semakin rendah tingkat pengetahuan pasien HIV maka cenderung semakin menurun tingkat keaktifan pasien untuk melakukan pencarian informasi terkait pelayanan pengobatan HIV di Puskesmas Dupak Kota Surabaya. Berdasarkan Tabel 4, keaktifan responden dalam melakukan pencarian informasi terkait pelayanan 
pengobatan di Puskesmas didominasi oleh responden dengan status keparahan pada stadium IV, sehingga dapat disimpulkan bahwa semakin tinggi status keparahan pasien maka semakin aktif pasien melakukan pencarian informasi pelayanan pengobatan di Puskesmas Dupak.

\section{Hubungan Karakteristik Individu dengan Tahap Evaluation of Alternative di Puskesmas Dupak}

Evaluation of alternative adalah proses mempertimbangkan setiap informasi yang telah didapatkan guna membandingkan untuk membuat pilihan terbaik secara keseluruhan sehingga dapat membuat keputusan sesuai dengan keinginan dan kebutuhan (Solomon et al, 2006). Tahap evaluation of alternative memiliki tiga konsep dasar dalam proses evaluasi yang dilakukan oleh konsumen yaitu konsumen memiliki usaha untuk mendapatkan keinginan dan kebutuhan, konsumen mencari manfaat dari solusi terhadap suatu produk atau jasa, konsumen mengasumsikan produk atau jasa sebagai atribut dengan kemampuan dan pelayanan yang berbeda dalam memberikan manfaat untuk memuaskan keinginan dan kebutuhan (Syafitri, 2012).

Berdasarkan Tabel 5, menunjukkan bahwa semakin muda umur pasien HIV positif, maka cenderung semakin aktif melakukan perbandingan pelayanan pengobatan di fasilitas kesehatan lainnya. Tabel 5 menunjukkan bahwa semakin rendah tingkat pendidikan pasien, maka pasien semakin tidak aktif untuk melakukan perbandingan pelayanan pengobatan HIV baik di Puskesmas Dupak maupun pada fasilitas layanan kesehatan lainnya. Tabel 5, menunjukkan bahwa semakin rendah tingkat pengetahuan pasien maka keaktifan pasien melakukan perbandingan pelayanan pengobatan di Puskesmas Dupak dengan fasilitas kesehatan lain cenderung semakin menurun. Tabel 5 menunjukkan bahwa semakin rendah status keparahan penyakit pasien, maka pasien semakin tidak aktif untuk melakukan perbandingan pelayanan pengobatan HIV baik di Puskesmas Dupak maupun dengan fasilitas layanan kesehatan lainnya.

Tabel 5. Hubungan Karakteristik Individu dengan Tahap Evaluation of Alternative Pengobatan HIV di Puskesmas Dupak

\begin{tabular}{|c|c|c|c|c|c|c|}
\hline \multirow{3}{*}{$\begin{array}{l}\text { Karak- } \\
\text { teristik }\end{array}$} & \multicolumn{4}{|c|}{$\begin{array}{c}\text { Evaluation of } \\
\text { Alternative }\end{array}$} & \multirow{2}{*}{\multicolumn{2}{|c|}{ Total }} \\
\hline & \multicolumn{2}{|c|}{ Aktif } & \multicolumn{2}{|c|}{$\begin{array}{c}\text { Tidak } \\
\text { Aktif }\end{array}$} & & \\
\hline & n & $\%$ & $\mathbf{n}$ & $\%$ & $\mathbf{n}$ & $\%$ \\
\hline Umur & & & & & & \\
\hline Remaja & 1 & 100,0 & 0 & 0,0 & 1 & 100,0 \\
\hline Dew: & 4 & 33,3 & 8 & 66,7 & 12 & 100,0 \\
\hline Lansia & 1 & 33,3 & 2 & 66,7 & 3 & 100,0 \\
\hline
\end{tabular}

Tingkat Pendidikan

$\begin{array}{lllllll}\text { SD } & 1 & 20,0 & 4 & 80,0 & 5 & 100,0 \\ \text { SMP } & 2 & 50,0 & 2 & 50,0 & 4 & 100,0 \\ \text { SMA } & 3 & 42,8 & 4 & 51,2 & 7 & 100,0\end{array}$

Pengetahuan

$\begin{array}{lrrrrrr}\text { Tinggi } & 5 & 62,5 & 3 & 37,5 & 8 & 100,0 \\ \text { Sedang } & 1 & 25,0 & 3 & 75,0 & 4 & 100,0 \\ \text { Rendah } & 0 & 0,0 & 4 & 100,0 & 4 & 100,0\end{array}$

Status Keparahan

\begin{tabular}{llrrrrr} 
Stad. I & 0 & 0,0 & 1 & 100,0 & 1 & 100,0 \\
Stad. II & 2 & 50,0 & 2 & 50,0 & 4 & 100,0 \\
Stad. III & 2 & 28,6 & 5 & 71,4 & 7 & 100,0 \\
Stad. IV & 2 & 50,0 & 2 & 50,0 & 4 & 100,0 \\
\hline
\end{tabular}

Keterangan: Stad. $=$ Stadium

\section{Hubungan Karakteristik Individu dengan Tahap Purchase di Puskesmas Dupak}

Purchase adalah keputusan pembelian dengan menentukan pilihan yang mengintegrasikan informasi dari berbagai sumber seperti pengalaman, kepercayaan, maupun informasi yang didapatkan saat melakukan pembelian (Solomon et al, 2006). Berdasarkan Tabel 6 , pada tahap pengambilan keputusan 
pengobatan di Puskesmas Dupak menunjukkan bahwa semakin tua umur pasien HIV positif, maka cenderung dipengaruhi oleh dorongan orang lain yang meliputi keluarga dan petugas kesehatan. Tabel 6 menunjukkan bahwa semakin tinggi tingkat pendidikan pasien, maka pengambilan keputusan untuk melakukan pengobatan di Puskesmas Dupak cenderung berasal dari diri sendiri.

Tabel 6. Hubungan Umur dengan Tahap Purchase Pengobatan HIV di Puskesmas Dupak

\begin{tabular}{|c|c|c|c|c|c|c|}
\hline \multirow{3}{*}{$\begin{array}{l}\text { Karak- } \\
\text { teristik }\end{array}$} & \multicolumn{4}{|c|}{ Purchase } & \multirow{2}{*}{\multicolumn{2}{|c|}{ Total }} \\
\hline & \multicolumn{2}{|c|}{$\begin{array}{c}\text { Diri } \\
\text { Sendiri }\end{array}$} & \multicolumn{2}{|c|}{$\begin{array}{c}\text { Doronga } \\
\text { n orang }\end{array}$} & & \\
\hline & $\mathbf{N}$ & $\%$ & $\mathbf{n}$ & $\%$ & $\mathbf{n}$ & $\%$ \\
\hline \multicolumn{7}{|l|}{ Umur } \\
\hline Remaja & 1 & 100,0 & 0 & 0,0 & 1 & 100,0 \\
\hline Dewasa & 9 & 75,0 & 3 & 25,0 & 12 & 100,0 \\
\hline Lansia & 2 & 66,7 & 1 & 33,3 & 3 & 100,0 \\
\hline
\end{tabular}

Tingkat Pendidikan

$\begin{array}{lrrrrrr}\text { SD } & 3 & 60,0 & 2 & 40,0 & 5 & 100,0 \\ \text { SMP } & 2 & 50,0 & 2 & 50,0 & 4 & 100,0 \\ \text { SMA } & 7 & 100,0 & 0 & 0,0 & 7 & 100,0\end{array}$

Pengetahuan

$\begin{array}{lrrrrrr}\text { Tinggi } & 5 & 62,5 & 3 & 37,5 & 8 & 100,0 \\ \text { Sedang } & 3 & 75,0 & 1 & 25,0 & 4 & 100,0 \\ \text { Rendah } & 4 & 100,0 & 0 & 0,0 & 4 & 100,0\end{array}$

Status Keparahan

$\begin{array}{lrrrrrr}\text { Stad. I } & 1 & 100,0 & 0 & 0,0 & 1 & 100,0 \\ \text { Stad. II } & 3 & 75,0 & 1 & 25,0 & 4 & 100,0 \\ \text { Stad. III } & 4 & 47,2 & 3 & 42,8 & 7 & 100,0 \\ \text { Stad. IV } & 4 & 100,0 & 0 & 0,0 & 4 & 100,0\end{array}$

Keterangan: Stad. $=$ Stadium

Tabel 6 menunjukkan bahwa semakin rendah pengetahuan pasien maka pengambilan keputusan pengobatan di Puskesmas Dupak cenderung berasal dari diri sendiri. Tabel 6 juga menunjukkan bahwa pengambilan keputusan pengobatan di Puskesmas Dupak yang berasal dari keputusan diri sendiri didominasi oleh responden dengan status keparahan pada stadium I dan stadium IV, sehingga semakin rendah status keparahan maka pengambilan keputusan pengobatan di Puskesmas Dupak cenderung berasal dari keinginan diri sendiri.

\section{PEMBAHASAN}

\section{Hubungan Karakteristik Individu dengan Proses Pengambilan Keputusan Pengobatan di Puskesmas Dupak}

Hasil penelitian ini menunjukkan bahwa keputusan pasien untuk melakukan pengobatan di Puskesmas Dupak mayoritas pada rentang umur dewasa awal yang termasuk dalam kategori umur yang matang untuk membuat suatu keputusan. Hal ini sesuai dengan penelitian yang dilakukan oleh Novita (2015) yang menyatakan bahwa umur seseorang mempengaruhi pengambilan keputusan karena pada kelompok dewasa cukup matang untuk memilih dan membeli sesuatu.

Hasil penelitian menunjukkan bahwa semakin tua umur maka semakin meningkatkan keinginan untuk melakukan proses pengambilan keputusan dalam melakukan pengobatn di Puskesmas Dupak. Menurut Solomon (2006), seiring dengan bertambahnya umur, maka kebutuhan dan preferensi juga berubah, sehingga umur memberikan pengaruh yang signifikan pada identitas dan cenderung tidak memiliki kesamaan dengan orang yang memiliki umur yang sama.

Tingkat pendidikan formal dapat meningkatkan daya nalar dan jalan untuk memudahkan seseorang untuk menerima motivasi dari lingkungan luar. Tingkat pendidikan juga dapat menentukan permintaan kesehatan, sehingga tinggi rendahnya terhadap permintaan pelayanan kesehatan dapat ditentukan oleh tinggi rendahnya pendidikan yang telah diperoleh (Setiawan, 2010). Hasil tabulasi silang antara tingkat pendidikan dengan proses 
pengambilan keputusan pada penelitian ini menunjukkan bahwa responden yang melakukan alur proses pengambilan keputusan pengobatan di Puskesmas Dupak sebagian besar didominasi oleh responden dengan tingkat pendidikan tamatan SD dan SMA. Hal ini menunjukkan bahwa semakin tinggi tingkat pendidikan responden, maka lebih cenderung untuk melakukan alur proses pengambilan keputusan. Hal ini sesuai dengan hasil penelitian yang dilakukan oleh Novita (2015) bahwa tingkat pendidikan formal yang tinggi lebih banyak melakukan pertimbangan sebelum memutuskan untuk memilih dan menggunakan pelayanan jasa.

Pegetahuan setiap orang memiliki tingkatan yang mempengaruhi perilaku atau tindakan yang diambil. Pengetahuan mempengaruhi kesadaran terhadap masalah kesehatan (Budiani, 2015). Menurut Sumarwan (2002), pengetahuan merupakan sebuah informasi yang dimiliki untuk mengetahui terkait suatu barang/jasa serta informasi yang berhubungan dengan manfaat dan fungsinya. Hal ini sesuai pada penelitian ini, yang menunjukkan bahwa keputusan responden untuk melakukan pengobatan HIV di Puskesmas Dupak menunjukkan bahwa mayoritas memiliki tingkat pengetahuan yan tinggi terkait dengan pelayanan pengobatan HIV. Semakin tinggi pengetahuan responden, maka semakin menurun keaktifan responden untuk melakukan proses pengambilan keputusan baik pada tahap problem recognition, information search, evaluation of alternative, maupun pada tahap purchase untuk melakukan pengobatan HIV di Puskesmas Dupak Surabaya.

Status keparahan pada penelitian ini dilihat dari tingkat stadium penyakit responden terhadap keputusan untuk melakukan pengobatan di Puskesmas Dupak menunjukkan mayoritas responden berada pada tingkat stadium III melakukan pengobatan di Puskesmas Dupak. Hasil pada penelitian ini menunjukkan bahwa terdapat peningkatan responden melakukan alur pengambilan keputusan seiring dengan tingkatan stadium yang semakin tinggi.

\section{SIMPULAN}

Berdasarkan hasil penelitian dan analisis pembahasan dapat disimpulkan bahwa responden yang terdiri dari 16 pasien HIV positif yang melakukan pngobatan di Puskesmas Dupak mayoritas pada rentang usia dewasa (26-45 tahun), pendidikan formal yang telah ditempuh responden sebagian besar tamatan sekolan menengah atas (SMA), dan pasien HIV positif memiliki tingkat pengetahuan yang tinggi terkait pengobatan HIV, serta status keparahan yang ditinjau dari tingkat stadium penyakit HIV yang diderita berada pada fase stadium III (simptomatik).

Berdasarkan data distribusi problem recognition, responden melakukan pengobatan yang didasari dengan keinginan diri sendiri, sehingga tidak ada peran yang mempengaruhi responden melakukan pengobatan di Puskesmas Dupak. Tahap information search, sebagian besar responden tidak aktif melakukan pencarian informasi mengenai pelayanan pengobatan baik di Puskesmas Dupak maupun di fasilitas kesehatan lainnya.

Data distribusi pada tahap evaluation of alternative, menunjukkan bahwa mayoritas responden tidak melakukan perbandingan dengan fasilitas kesehatan lainnya, sehingga informasi yang didapatkan terkait dengan pelayanan pengobatan HIV hanya berasal dari petugas kesehatan maupun pihak LSM yang memberikan penyuluhan (Dwinada, 2012). Responden cenderung mengikuti alur dan saran dari petugas kesehatan. Keputusan untuk melakukan pengobatan di Puskesmas Dupak sebagian besar berasal dari keinginan diri responden tanpa adanya pengaruh dari keluarga, kelompok referensi yang meliputi teman, pengalaman seseorang, maupun petugas kesehatan di Puskesmas Dupak. 
Berdasarkan kesimpulan dari hasil penelitian, maka dapat dikemukakan beberapa saran bagi Puskesmas Dupak yaitu dengan meningkatkan program sosialisasi terkait HIV melalui kegiatan promosi dan diskusi interaksi dengan petugas kesehatan untuk meningkatkan pengetahuan pasien. Berdasarkan hasil responden yang kurang aktif melakukan pencarian informasi, maka sebaiknya pihak Puskesmas Dupak perlu memberikan informasi terkait pelayanan pengobatan HIV melalui media cetak maupun media elektronik sebagai bentuk penyampaian informasi sehingga dapat digunakan sebagai referensi untuk membandingkan pelayanan pengobatan di Puskesmas Dupak dengan fasilitas kesehatan lainnya.

\section{DAFTAR PUSTAKA}

Adithyan G.S., 2016. A Study on HIV Knowledge and Preventive Behavioral Practice Among FWF'S in Mumbai. Journal. Academic Journal: Journal of AIDS and HIV Research.

Ardhiyanti, Y., Novita, L., and Kiki, M., 2015. Bahan Ajar AIDS pada Asuhan Kebidanan. Cetakan pertama: Yogyakarta: Deepublish.

Arwyn, N., Sanfia, T., and Sevnat J., 2017. Faktor yang Mempengaruhi Pengambilan Keputusan dalam Penggunaan Layanan Kesehatan pada Wilayah Kerja Puskesmas Tawiri. Salatiga: Universitas Kristen Satya Wacana.

Budiani, W., 2015. Pengaruh Motivasi Konsumen dan Konformitas Kelompok Terhadap Keputusan Membeli Tas Branded Imitasi. Skripsi: UIN Syarif Hidayatullah.

Center for Disease Control and Prevention. 2016. HIV/AIDS Transmission. USA: U.S. Departement of Health \& Human Services.

Ditjen PP dan PL Kemenkes RI. 2014. Statistik Kasus HIV/AIDS di Indonesia Dilapor s/d September
2014/ [pdf] Indonesia; Ditjen PP dan PL Kemenkes Republik Indonesia.

Ditjen PP dan PL Kemenkes RI. 2014. Statistik Kasus HIV/AIDS di Indonesia Dilapor s/d Maret 2016. [pdf] Indonesia: Ditjen PP dan PL Kemenkes RI.

Dwinada, F., 2012 Analisis Faktor-Faktor Keputusan Pembelian Minyak Goreng Kemasan Merek Bimoli (Studi Kasus: Rumah Tangga di Kota Bogor). Skripsi: Institut Pertanian Bogor.

Effendy, N. A., 2012. Analisis Faktor yang Berpengaruh Terhadap Pengambilan Keputusan Pemilihan Tempat Persalinan Oleh Ibu di RSIA Nyai Ageng Pinatih Gresik. Skripsi: Universitas Airlangga.

Elly, N., and Mustikasari., 2009. Faktor Pencegahan HIV/AIDS Akibat Perilaku Berisiko Tertular pada Siswa SLTP. Depok: Universitas Indonesia.

Gita, F., and Nurrobikha., 2015. Etikolegal dalam Pelayanan Kebidanan. Edisi I. Cetakan I. Yogyakarta: Deepublish.

Inggit, R., Veny, R., and Abdul K., 2017. Hubungan Tingkat Pengetahuan Tentang HIV/AIDS dengan Perilaku Seksual Pranikah Pelajar. Jurnal: Akademi Kebidanan Riau.

Keputusan Menteri Kesehatan Republik Indonesia Nomor 1507 Tahun 2005 Tentang Pedoman Pelayanan Konseling dan Testing HIV Secara Sukarela (Voluntary Counselling and Testing). Jakarta: Kementerian Kesehatan.

Keputusan Menteri Kesehatan RI. 2011. Pedoman Nasional: Tatalaksana Klinis Infeksi HIV dan Terapi Antiretroviral pada Orang Dewasa. Jakarta: Kementerian Kesehatan.

Komisi Penanggulangan AIDS Nasional. 2009. HIV dan AIDS Sekilas Pandang. Edisi Kedua: Jakarta. 
Marquis and Huston. 2010. Kepemimpinan dan Manajemen Teori dan Aplikasi Alih Bahasa Widyawati dan Handayani. Edisi 4. Jakarta: EGC.

Notoatmojo, S., 2003. Pendidikan dan Perilaku Kesehatan. Jakarta: Rineka Cipta.

Peraturan Menteri Kesehatan Repubik Indonesia Nomor 21 Tahun 2013 Tentang Penanggulangan HIV dan AIDS. Jakarta: Kementerian Kesehatan.

Peraturan Menteri Kesehatan Republik Indonesia Nomor 51 Tahun 2013 Tentang Pedoman Pencegahan Penularan HIV dari Ibu ke Anak. Jakarta: Kemeterian Kesehata.

Peraturan Menteri Kesehatan Republik Indonesia Nomor 75 Tahun 2014 Tentang Pelayanan Kesehatan Masyarakat. Jakarta: Kementerian Kesehatan.

Schiffman, L. G., and Kanuk, L., 2007. Perilaku Konsumen. Edisi Ketujuh. Jakarta: Prentice Hall inc.

Setiawan, A. P., 2010. Faktor yang Mempengaruhi Pemanfaatan Rawat Inap Berdasarkan Perilaku Konsumen dan Mutu pelayanan Kesehatan di Puskesmas Sidoarjo. Skripsi Thesis: Universitas Airlangga.
Solomon, M., Gary, B., Soren, A., and Margaret, K, Hogg., 2006. Consumer Behavior A European Perspective: Third Edition. Pearson Education Limited.

Sumarwan. 2002. Perilaku Konsumen Teori dan Penerapannya. Jakarta: Ghalia Indonesia.

Sugiana. 2015. Analisis Kesiapan Layanan Puskesmas sebagai Satelit Antiretroviral Therapy bagi Orang dengan HIV/AIDS (ODHA) di Kabupaten Badung. Tesis: Universitas Udayana.

Swasta dan Irawan. 2005. Manajemen Pemasaran Modem. Yogyakarta: Liberty.

Syafitri, L., 2012. Faktor-Faktor yang Berhubungan dengan Pemanfaatan Pelayanan Pitc bagi Tahanan dan Warga Binaan Pemasyarakatan (Wbp) Berisiko Tinggi HIV/AIDS di Poliklinik Rutan Klas I Cipinang Tahun 2012. Tesis: Universitas Indonesia.

Trihono., 2005. Arrimes Manajemen Puskesmas Berbasis Paradigma Sehat. Cetakan Ke-I. Jakarta: Sagung Seto. 